\title{
Web Based Medical Education Management System; Special Brief Result Report
}

\author{
Web Tabanlı Tıp Eğitimi Yönetim Sistemi Geliştirilmesi; Özel Sonuç Raporu Özeti
}

Ibrahim Başhan *1, Yücel Uysal ${ }^{2}$

\begin{abstract}
Medical education is a tough process because of particular diversity of medical profession. It's a challenging work to keep appropriate education standards because of limited physical conditions and limited number of instructors of medical schools. The only short term solution seems to use time and resorces more efficiently. An ample amount of parameters are present to consider for planning and conducting medical education. Especially in medical schools which have limited resources it's hard to evaluate and improve quality of education. In this project a comprehensive structure was designed for manager instructors and managers of medical faculty to control and follow many parameters of education process. Managers can reorganize labor resources properly through this sytem. Other modules that would facilitate management of education besides the standard education data and modules were also integrated into the system; 'committee/commission work modules'(with electronic document management system), 'question bank module', 'National Core Education Program compatibility module'. Current databases and interfaces in the project have revealed the complicated side and the excessive amount of data in medical education. As the system was designed as fexible and modular, both databases and user interfaces could be increased and decreased horizontaly and vertically if required. Data tables of management system were structered as 'relational database management system'; as all tables are connected to each other with common keys and values. This structure allows to reorganize the related data automatically after changing some values. Also calculating algorithms and scripts were structured as modular that allows the system work faster. Virtual data were entered to system, essential tests were conducted, and the outputs were controlled and confirmed manually. This system could be optimized by time according to feedback of users, as all novel systems.
\end{abstract}

Keywords: Medical education, web-based management system

\section{ÖZET}

Zorlu tıp eğitimi sürecine ilişkin sorunların kısa vadeli çözümü; zamanı ve mevcut kaynakları daha verimli şekilde kullanmaktır. Tıp eğitiminin planlanması ve yürütülmesi sırasında göz önünde tutulması ve değerlendirilmesi gereken çok fazla parametre mevcuttur. Özellikle insan gücü ve diğer fiziksel kaynakların sınırlı olduğu üniversitelerde kısıtlı imkanlarla eğitim kalitesini değerlendirmek ve geliştirmek zorlu bir mücadeledir. Sonuç özeti sunulan bu projede özellikle tıp eğitimine ilişkin yönetici ve karar verici öğretim üyelerinin ve tıp fakültesi yönetiminin eğitim sürecine ilişkin olabildiğince fazla parametreyi gözleyebileceği, kontrol edebileceği ve toplam iş gücünü kısıtlı kaynaklara uygun şekilde dağıtacak planlamalar yapabileceği bir yapı oluşturulmuştur. Sistem tasarlanırken sadece eğitime ilişkin parametreler değil, yönetimi kolaylaştıracak; kurul çalışma modülleri (elektronik belge yönetim sistemi dahil), soru bankası modülü, Ulusal Çekirdek Eğitim Programı Uyumluluk Modülü gibi ek modüllerde sisteme entegre edilmiştir. Projede yer alan veri tabanları ve ara yüzler, tıp eğitiminin karmaşık yapısını ve yönetilmesi gereken veri büyüklüğünü ortaya koymaktadır. Projede gerçeklenen sistem esnek ve modüler olduğu için gerek veri tabanları gerek ara yüzler farklı istekler doğrultusunda dikey ve yatay eksenlerde artırılabilecek veya azaltılabilecektir. Yönetim sistemine ilişkin veri tabloları 'ilişkisel veri tabanı yönetim sistemi' mantığ birbirine bağlanmıştır. Farklı modüllerde yapılan değişiklikler tüm sistemdeki ilişkili tablolarda otomatik olarak uygun düzenlemeleri sağlamaktadır. Veri tabanı yapıları gibi hesaplama algoritmaları da modüler tarzda geliştirildiği için sistem üzerine aşırı yük bindirmeden gerekli hesaplamalar ve düzenlemeler hızlıca yerine getirilmektedir. Sisteme proje süresi boyunca sanal veriler yüklenmiş, gerekli testler gerçeklenmiş, çıktıların manüel kontrol ve doğrulamaları yapılmıştır. Her yeni geliştirilen sistemde olduğu gibi bu sistem de kullanıldıkça zaman içinde kullanıcılardan gelecek geri bildirimler çerçevesinde geliştirilmeye devam edilecektir.

Anahtar kelimeler: Tıp eğitimi, web tabanlı yönetim sistemi

Received / Geliş tarihi: 26.02.2018, Accepted / Kabul tarihi: 23.05.2018

${ }^{1}$ Mersin Üniversitesi Tıp Fakültesi Tıp Eğitimi Anabilim Dalı

${ }^{2}$ Mersin Üniversitesi Tıp Fakültesi Aile Hekimliği Anabilim Dalı

*Address for Correspondence / Yazışma Adresi: İbrahim Başhan, Mersin Üniversitesi Tıp Fakültesi Tıp Eğitimi Anabilim Dalı, Mersin-TÜRKiYE, Email: ibashan@yahoo.com

Başhan İ, Uysal Y. Web Tabanlı Tıp Eğitimi Yönetim Sistemi Geliştirilmesi; Özel Sonuç Raporu Özeti. TJFMPC, 2018;12 (3): $200-214$.

DOI: $10.21763 /$ tjfmpc. 452475 


\section{GíRiș}

Bu çalışmada TÜBİTAK-3001 Başlangıç AR-GE Projeleri Destekleme Programı tarafindan kabul edilen ve desteklenen "Web Tabanlı Tıp Eğitimi Yönetim Sistemi Geliştirilmesi" başlıklı projenin sonuçları özetlenmektedir. Proje Nisan 2014 ve Aralık 2016 tarihleri arasında yürütülmüş ve başarılı bir şekilde sonlandırılmıştır. Toplam proje bütçesi 38.000 \$ olarak gerçekleşmiştir. Bu miktarın 33.000 \$'1 TÜBİTAK desteği ile, kalan 5.000 \$'1 proje ekibi tarafindan karşılanmıştır.

Ülkemizde tıp fakültesi ve tıp fakültesi başına düşen öğrenci sayısının hızlı artışı tıp eğitiminde bazı zorlukları ve sorunları öne çıkarmaktadır. ${ }^{1}$ Fakülte ve öğrenci sayısıyla paralel olarak öğretim üyesi sayısında ve diğer fiziksel koşullarda yeterince gelișme sağlanamadığından mevcut durumda her fakülte kapasitesinin üzerinde sayıda öğrenciye eğitim ve öğretim verme durumundadır. ${ }^{2}$ Öğretim üyesi başına düşen öğrenci sayısındaki artış tıp eğitiminin önemli eğitim yöntemlerinden biri olan "usta çırak ilişkisine dayalı eğitim ve öğretim" modelinin uygulanmasında güçlükler ortaya çıkarmıştır. Pratik uygulamalar tıp eğitiminde mezuniyet öncesi eğitimin önemli bir bölümü oluşturmaktadır. Mevcut durumda öğrenci sayısının fazlalığı nedeniyle tıp eğitimi sırasında zaman ve enerjinin büyük bölümü teorik eğitime harcanmakta, pratik uygulamalar ve becerilerin geliştirilmesi konusunda yeterince çalışma yapılamamaktadır. Eğitim ve öğretim sürecinde öğrencilerden geri bildirimler alınması, aktif katılımı ve etkileşimi arttıracak, hem bilgi ve becerilerin öğrenilmesini kolaylaştıracak hem de daha kalıcı olmasını sağlayacaktır.

Tüm bu sıkıntılar tıp eğitiminin kendine özgü farklılığ 1 ve zorlukları ile birleştiğinde eğitimin standardizasyonu ve standardize edilmiş eğitim çıktılarının takibi ve değerlendirilmesi üstesinden gelinmesi gereken en önemli zorluklardan biri olarak görünmektedir.

Bu bağlamda tıp eğitiminde mevcut duruma ilişkin sorunlar ve zorluklar şu şekilde sıralanabilir:

1. Son yıllarda tıp fakültesi sayısında çok hızlı bir artış olmuştur; 1990 yılında öğrenci kabul eden tıp fakültesi sayısı 25 iken 2012 yılında öğrenci kabul eden tıp fakültesi sayısı özel ve vakıf üniversiteleri ile birlikte 100'ü aşmıştır. "Bir milyon nüfusa düşen tıp fakültesi sayısı" Kuzey Amerika'da 0.62 , Avrupa'da 0.54 , dünya genelinde 0.30 iken Türkiye'de bu oran 1.02 'dir. $^{2}$

2. Öğrenci artış oranı ile öğretim üyesi artıș oranları paralel olmadığından öğretim üyesine düşen öğrenci sayısı hızlı bir artış göstermektedir.
3. Öğenci sayısındaki fazlalık ve tıp fakültelerinin fizik koşullarındaki yetersizlikler nedeniyle eğitim ve öğretim sürecinde öğretim üyesi ve öğrenciler yeterince biraraya gelememekte ve pratik uygulamalara ve beceri eğitimlerine yeterince zaman ayrılamamaktadır.

4. Tıp fakültesi eğitim ve öğretim müfredatları ayrıntılı şekilde hazırlanmakta fakat öğrencilerin müfredatta yer alan bilgi ve becerileri ne düzeyde kazandıklarının ölçülmesi ve değerlendirilmesinde zorluklar yaşanmaktadır. ${ }^{3}$

5. Özellikle beceri ve pratik uygulamaların ölçülmesi, değerlendirilmesi ve takibinde tıp fakülteleri arasında standardizasyon eksikliği mevcuttur. ${ }^{4}$

6. Türkiye'de ve dünyada tıp fakültelerinin verdiği eğitim ve öğretimi değerlendiren ve akredite eden bazı dernekler ve sivil toplum kuruluşları mevcuttur ve tıp fakültelerinin akreditasyon ve standardizasyon süreölerine ciddi olumlu katkılar sağlamaktıdırlar. Ancak, bu süreç ciddi bir evrak yükünü de beraberinde getirmekte ve evrakların takibi hem denetleyenler hem de denetlenenler için oldukça zor olmaktadır.

7. Tıp eğitimine ilişkin iş yükü tıp fakültesinin toplam idari iş yükünün büyük kısmını oluşturduğu için tıp eğitimindeki eksikler ve zorluklar dolaylı olarak tıp fakültesi yönetimine yansımaktadır.

8. Tüm tıp fakültelerinde, standart olmamakla birlikte, fakülte yönetimi ve tıp eğitimine ilișkin pek çok değerlendirme ve idari yönetim formları mevcuttur. Öğretim üyelerine ve öğrencilere yönelik hazırlanan bu formların dijital ortamda yapılandirılmamas1 ve doldurulmamas1 nedeniyle elde edilen bilgilerin değerlendirilmesi ve takibi zorlaşmakta ve bu bilgilere dayalı ileriye dönük projeksiyonların yapılması imkansız hale gelmektedir.

9. Tıp eğitimi ve tıp fakültesi yönetiminde bilgilerin dijital ortama aktarılması konusunda ciddi düzeyde endişe ve çekinceler mevcuttur. $\mathrm{Bu}$ endişeler nedeniyle soru bankaları dahil tıp eğitiminin yönetimine ilişkin analizler yapılmasını sağlayacak pek çok bilgi dijital ortam yerine basılı ortamda tutulmakta ve bu durum bilgilerin güncellenmesini, takibini ve değerlendirilmesini imkansız hale getirmektedir. ${ }^{5}$

10. Tıp mesleğinin diğer mesleklerden farklı bazı özellikleri nedeniyle öğrencilerin eğitim süresince mesleki gelişimlerinin ölçülmesi ve değerlendirilmesi klasik bilgi ölçme ve 
değerlendirme sistemlerinden fazlasını gerektirmektedir. Teorik bilginin dışında iletişim, triaj, empati ve benzeri bazı standart dışı subjektif mesleki gelişim özelliklerinin ölçülmesi ve değerlendirilmesi farklı kriterler çerçevesinde yapılmalıdır. Bu durum, tıp fakültesi öğrencilerini bilgi ve beceri yönünden değerlendirmeyi daha zor ve karmaşık hale getirmektedir. ${ }^{6}$

11. Özellikle son yirmi yıl içinde bilişim sistemleri çok farklı sektörlere hızlı şekilde entegre edilmiştir. Ülkemizde bilişim sistemleri, sağlık alanında tanı ve tedavi hizmetlerine hızlı şekilde entegre edildiği halde tıp eğitimi ve sağlık yönetimi alanında bilişim sistemlerinin kullanımı oldukça sınırlı kalmıştır. ${ }^{7} \mathrm{Bu}$ süreçteki en önemli direnç noktası, bilişim sistemlerinin tıp eğitimine ileri derecede entegre edilmesinin tıp eğitiminin vazgeçilmez temelini oluşturan "usta-çırak ilişkisine dayalı eğitim modeli"ne zarar vereceği endișesidir. Ayrıca bilişim sistemlerini farklı alanlara uyarlama konusunda bilgi ve tecrübe eksikliği nedeniyle bilişim teknolojilerini ihtiyaçlara uygun olarak şekillendirmede zorluklar yaşanmaktadır. Özellikle tıp eğitimi ve yönetimine ilişkin işlerimizi kolaylaştıracağı düşünülen yazılımları oluşturma işi uygun şekilde yönetilemez ve yazılımcılar iyi yönlendirilemezse oluşturulan sistemler işleri kolaylaştırmaktan çok zorlaştırabilir ve karmaşık hale getirebilir.

$\mathrm{Bu}$ projede bilişim sistemlerinin etkin ve yaygın kullanılmasını sağlayarak tıp eğitiminde stabil, gelişmeye açık, esnek ve erişimi kolay bilgi depolama ve analiz altyapısı oluşturulması hedeflenmiştir. Bu sistem sayesinde henüz yolun çok başında olunan tıp eğitimi alanında referans bir bilgi analiz altyapısı oluşturulması ve önümüzdeki dönemlerde ortaya çıkacak yeni sorun ve ihtiyaçlar doğrultusunda bu sistemin geliştirilmesi ve güncellenmesi mümkün olacaktır.

Ülkemizde yeni bir kavram olan "tıp eğitimi" alanında yapılmış özgün çalışma ve yayın sinırlıdır. Driessen ve ark. (2007)' nın yaptığ 1 bir çalışmada tıp eğitiminde kişisel gelişim dosyası ile takip ve değerlendirme sisteminin ortaya koyduğu olumlu gelişmeler ve başarılar sistematik bir derlemede ele alınmıştır. ${ }^{8}$ Projede gerçeklenen kişisel gelişim dosyası(portfolyo) sisteminin webtabanlı olarak dizayn edilmesi yönetimsel olarak ek kolaylıklar ve olumlu etkiler sağlayacaktır.

Tıp eğitimini objektif kriterler çerçevesinde ölçmek ve değerlendirmek zor gibi görünmektedir. Lurie ve ark. bu konuda yaptığı çalışmada mevcut değerlendirme araçlarının sınırlı başarısı ortaya konmuştur. ${ }^{9} \mathrm{Bu}$ zorluğa ek olarak tıp fakültelerinde standardize edilmiş ve yapılandırılmış bir takip ve değerlendirme sistemi mevcut değilse farklı tıp fakültelerini bu bağlamda değerlendirmek ve aralarında eğitim standardizasyonu sağlamak yoğun bir emek gerektirmektedir. Bu proje ile geliştirilen sistemin en önemli katkılarından biri de bu standardizasyon ve değerlendirme sürecine olacaktır.

Geliştirilen bu yönetim sisteminin, tıp eğitimine ilişkin yukarıda sıralanan sorun ve zorluklara, yönetim kolaylığı, zamanın verimli kullanımı, işgücü kaynaklarının uygun yönetilmesi, eğitim verilerinin elektronik ortamda saklanması ve analizi, bilişim teknolojilerinin tıp eğitiminde etkin kullanılması bağlamında çözümler üretmeye katkıda bulunacağı öngörülmektedir.

Sistemin önemli bileşenlerinden birisi tıp öğrencilerinin başarı değerlendirmesinde portfolyo bileşenleri takiplerinin olmasıdır. Burada portfolyo bileşenleri olarak anılan faaliyetler klinik pratik, beceri ve uygulama çalışmalarıdır. Eğitim öğretim faaliyetlerinin değerlendirilmesi sürecine kişisel gelişim dosyası (portfolyo) bileşenlerinin eklenmesi, not sisteminde ve eğitim öğretim süresi içinde oranının artırılması ve bu bileşenlerin başarı değerlendirmesinde aktif kullanımının pek çok avantajı olacaktır. ${ }^{10}$

\section{GEREÇ VE YÖNTEM}

Projede yazılım altyapısı için açık kaynak kodlu olmas1, maliyet-etkin olmas1, uygulama ve kavrama kolaylığı, yaygın kullanımı, esnek yapılandırmalara ve düzenlemelere izin verebilmesi, sadece sunucu taraflı işlemlere izin vermesi (güvenli arayüzler ve iletişim süreçlerine imkan sağlaması) nedeniyle Linux sunucu üzerinde çalışan web tabanlı açık kaynak kodlu betik dili olarak PHP (=Hypertext Preprocessor $)^{11}$ ve veri tabanı yönetim sistemi olarak PHP ile uyumlu şekilde çalışan MySQL ${ }^{12}$ veri tabanı yönetim sistemi seçilmiştir. Gerekli yerlerde Javascript ve HTML betikleri entegre edilmiştir. Arayüzler tasarlanırken olabildiğince modern ve güncel internet tarayıcılarda(Chrome, Firefox, Opera vs.) aynı tepkilerle çalışacak şekilde düzenlemeler yapılmıştır. Farklı cihazlarda sorun çıkarma potansiyeli olan Flash veya Silverlight gibi geliştirme araçları kullanılmamıştır. Veriler ve betikler internete bağlı uzak sunucu üzerinde yapılandırılmış ve eşzamanlı olarak yerel bilgisayarlarda ve farklı uzak sunucularda yedeklenmiştir.

Projenin birinci iş paketinde tamamlanan çalışmalar maddeler olarak şu şekilde özetlenebilir;

- Yazılım geliştirme ortamı hazırlıkları,

-Alan ve barındirma tedariki, gerekli ayarların yapılması, test edilmesi,

-Sunucu tarafindaki klasör sistemlerinin düzenlenmesi, 
yap1lmas1,

-Sunucu kontrol panel ayarlamalarının

- Veri tabanı ön hazırlıklarının yapılması,

- Sunucunun test edilmesi,

- Proje ekibinin eğitimi ve ekip üyelerinin iş paketleri çerçevesinde iş yükü dağılımlarının yapilmas1,

-Kullanic1 gruplarının belirlenmesi, kullanıcıların asgari veri setlerinin belirlenmesi,

- Kullanıcılara ilişkin verilerin veri tabanına girilmesi,

Projenin ikinci iş paketinde tamamlanan çalışmalar maddeler olarak şu şekilde özetlenebilir;

-Öğretim üyelerinin eğitim faaliyetlerini değerlendirmede kullanılacak parametrelerin belirlenmesi ve veri tabanının buna göre yapılandırılması,

-Dönem 1, 2 ve 3'deki teorik derslere ilişkin pratik sınav, teorik sınav, dönem 4 ve 5 'deki teorik derslere ilişkin yazılı sınav ve sözlü sınav not girişlerinin yapılmasını sağlayacak veri tabanı yapılandırmalarının gerçeklenmesi,

-Bu notların hangi oran ve katsayılarla hesaplanacağına ilişkin algoritmaların belirlenmesi,

-Dönem 1， 2, 3, 4, 5 ve 6'daki beceri/uygulama/pratiklerden oluşan portfolyo bileşenlerine ilişkin not sisteminin düzenlenmesi, oran ve katsayıların belirlenmesi, buna uygun veri tabanı hazırlıklarının yapılması,

-Öğrencilere portfolyo çalışmaları öncesi erişime açılacak ve sunulacak çalışma dosyalarına ilişkin veri tabanı çalışmalarının yapılması,

-Öğrencilerin her portfolyo bileşenine ilişkin sisteme yükleyecekleri dosyalara ilişkin veri tabanı çalışmalarının yapılması, sunucu üzerinde gerekli klasör yapılandırmalarının gerçeklenmesi,

-Tüm bu verilerin hangi yetki düzeyindeki kullanıcılar tarafından girileceğinin, takip edileceğinin ve değerlendirileceğinin belirlenmesi,

Projenin üçüncü ve dördüncü iş paketinde tamamlanan çalışmalar maddeler olarak şu şekilde özetlenebilir;

-Veri tabloları arasındaki ilişkisel bağlantıyı sağlayacak anahtar verilerin belirlenmesi,

-Notlara ilişkin ve diğer istatistiksel analizlere ilişkin hesaplamaları yapacak betiklerin hazırlanmasi, test edilmesi,

-Veri giriş arayüzlerinin hazırlanması,

-Tablo yapılarının düzenlenmesi,

-Soru bankası modülünün test edilmesi, soru bankasına modülüne özgü ayrıntılı istatistiksel analiz betiklerinin hazırlanması, soru bankası modülü ile yönetim sisteminin entegrasyonunun sağlanması,

-Fakülte kurul çalışmalarına ilişkin veri tabanı ve arayüz çalışmalarının yapılması, kurul/komisyon çalışmaları sırasında kullanılacak elektronik belge yönetim sisteminin geliştirilmesi,
-Mesaj modülünün hazırlanmas1,

-Teorik ders ve portfolyo bileşenlerine ilişkin Ulusal Çekirdek Eğitim Programı ${ }^{13}$ uyumluluk durumunu gösterecek ek parametrelerin veri tabanlarına eklenmesi,

-Soru bankasını modülünün güvenliğini artırmak amacıyla "giriş/login" sırasında kullanılacak sms(kısa mesaj servisi) modülünün hazırlanması ve entegre edilmesi,

-Tüm modüllere yeterli miktarda veri girilerek farklı senaryolar çerçevesinde sistemin test edilmesi.

\section{BULGULAR}

$\mathrm{Bu}$ bölümde yönetim sisteminin ana modülleri tanıtılacak ve sistemin çalışmasına ilişkin özet bilgiler verilecektir. Burada görülen ekran görüntüleri 'Sistem Yöneticisi' yetki düzeyine sahip bir kullanıcının ekran görüntüleri olarak yansıtılmıştır. Sistem yöneticisinin tüm verilere erişim yetkisi olduğu için bu şekilde sistemin tüm modülleri tanıtılacak, gerekli yerlerde hangi verileri kimlerin girebileceği veya izleyebileceği belirtilecektir.

\section{Login/Giriş İşlemi ve Yetki Düzeylerine Göre Kullanıcı Grupları}

Sistem kullanıcıları, açılıș ekranı ile karşılamaktadır. Bu ekranda kullanıcı adı ve şifre girildikten sonra bir sonraki ekranda "giriş/login" işlemi doğrulanmakta ve yine aynı ekranda giriş yapan kullanıcının yetki düzeyleri görülmektedir. Sistemde bir öğretim üyesinin farklı görev tanımlarına paralel olarak farklı yetki düzeyleri tanımlanmıştır. Örneğin bir öğretim üyesi ör. hem 'Dönem Koordinatörü' yetkisine sahip olabilir hem de 'Danışman Öğretim Üyesi' yetkisiyle sistemdeki görev ve sorumluluklarını yerine getirebilir. Ya da 'Staj Sorumlusu' olan bir öğretim üyesinin aynı zamanda 'Eğitici Öğretim Üyesi' görevi bulunabilir. Sistemde tanımlı kullanıcı grupları şunlardır; 1. Tıp eğitiminden sorumlu yönetici öğretim üyeleri (Dekan, Dekan Yardımcıları, Tıp Eğitimi Anabilim Dalı Başkanı, Lisans Eğitimi Koordinatörler Kurulu Başkanı vb.), 2. Dönem koordinatörü öğretim üyeleri, 3. Dönem koordinatör yardımcısı öğretim üyeleri, 4. Staj sorumlusu öğretim üyeleri, 5. Eğitici öğretim üyeleri, 6. Danışman öğretim üyeleri, 7. Öğrenci işleri personeli, 8. Öğrenciler.

\section{'Yönetici Giriş Ekranı' Bağlantısıyla Erişilen Arayüz ve Menü Yapısının Ana Başlıkları}

Bu giriş sayfası arayüzünde solda dikey bir menü ve üst kısımda yatay bir menü mevcuttur (Şekil 1). Bu ekranda dikey ve yatay menüler hemen hemen aynı bağlantıları göstermektedir. Fakat herhangi bir bağlantıya tıklandığında üst kısımdaki yatay menü 
tıklanan bağlantının içeriğine göre alt bağlantıları gösterirken soldaki dikey menü tüm sayfalarda değişmeden kalmaktadır. Böylece her bölümden sistemin tüm alt bölümlerine tek tıkla doğrudan erişim imkanı mevcuttur. Menü sisteminde yer alan başlıklar ve alt başlıklar şunlardır;

- 'Teorik Dersler / Portfolyo Bileşenleri' bağlantısı; bu bağlantı altında dönemlere göre sınıflandırılmış teorik ders ve portfolyo bileşenleri başlıklarına şematik bir şekil üzerinden erişilebilmektedir.

- 'Ders Kodları (Dönem 1, 2, 3)' bağlantısı; Dönem 1,2 ve 3 'de teorik derslere ilişkin ders isimleri ve ders kodlarına bu bağlantıdan erişmek mümkündür.

- 'Teorik Ders Konuları (D1, D2, D3, D4, D5)' bağlantısı; Dönem 1, 2, 3, 4 ve 5'deki teorik ders konuları ve bu konulara ilişkin parametrelere bu bağlantı ile erişmek mümkündür.

- 'Portfolyo Bileşenleri (D1, D2, D3, D4, D5, D6)' bağlantıs1; Dönem 1, 2, 3, 4, 5 ve 6'daki uygulama/pratik ve beceri çalışmalarına (portfolyo bileşenleri) bu bağlantı üzerinden erişmek mümkündür.

- 'Stajlar (Dönem 4, 5, 6)' bağlantısı; Dönem 4, 5 ve 6'daki stajlar ve kodları bu bölümde yer almaktadır.

- 'Teorik Ders Konuları / Portfolyo Bileșenleri; Sayı ve Süre Verileri' bağlantısı; bu bölümde hem ögrretim üyesi bazında hem de anabilim dalları/bölümler bazında teorik derslerin ve portfolyo çalışmalarının sayıları ve süreleri gösterilmektedir.

- 'Öğretim Üyeleri' bağlantısı; öğretim üyelerine ilişkin sınıflandırmalar, erişim şemaları ve diğer öğretim üyeleri verileri bu bölümde yer almaktadır.

- 'Soru Bankası Modülü' bağlantısı; bu bağlantıya tıklandığında ayrı bir sayfada dijital soru bankası modülü açılmaktadır.

- 'Kurul/Komisyon Calıșma Modülleri' bağlantısı; bu bölümde tıp eğitimiyle ilişkili bazı kurul veya komisyonların çalışmaların takip edilebildiği sayfalar yer almaktadır. Bu bölümde ayrıca elektronik belge yönetim sistemi de mevcuttur.

- 'Mesaj Modülü' bağlantısı; kullanıcılar arasında iletişimi sağlayan bölüm bu bağlantı altında yer almaktadır. Mesajlaşma; sistem üzerinden, e- posta ile veya sisteme entegre edilen sms arayüzü üzerinden yapılabilmektedir.

-'Hesaplama Katsayıları/Oranları' bağlantıs1; sistemde notların hesaplanmasında kullanılan oran ve katsayılara bu bölüm üzerinden erişmek ve değiştirmek mümkündür. Oran ve katsayılar değiştirildiğinde otomatik olarak tüm hesaplamalar yeni belirlenen rakamlara göre yapılacaktır.

-'Proje Takip Sayfaları' bağlantısı; bu geçici bir bağlantıdır. Projenin ilerleyişine ilişkin takip edilmekte olan bazı bölümlere ve verilere bu bağlantı üzerinden erişmek mümkündür. Proje sonlandıktan sonra bu bağlantı kaldırılmıştır.

\section{'Teorik Dersler / Portfolyo Bileșenleri' Bölümü}

$\mathrm{Bu}$ bölümde Dönem 1'den 6'ya kadar tüm dönemlerdeki teorik dersler ve portfolyo bileşenleri yer almaktadır. Dönem 1, 2 ve 3'de dersler ve portfolyo bileşenleri ders kurullarına göre ayrılmıştır, dönem 4, 5 ve 6'da ise stajlara göre ayrılmıştır.

Teorik ders konularını farklı parametrelere göre siralamak mümkündür. Sistemde teorik ders konularına ilişkin şu parametreler yer almaktadır; 1. Ders konusunun kodu; bu kod 26 veya 27 haneden oluşan ve içerisinde ders konusunun tarih, saat, konu alt kodu ve süre bilgilerini barındırmaktadır.

2. Ders konusunun hangi dönemde(sinıfta) yer aldığı.

3. Ders konusunun o dönem içindeki hangi kaçıncı ders kurulunda veya hangi stajda yer aldığ

4. Dönem 1, 2 ve 3'deki dersler için ders konusunun eğitim öğretim rehberinde yer alan ders kodu,

5. Konunun bağlı olduğu dersin ad1,

6. Yedi haneli konu kodu,

7. Konunun adı; her konu adının sonunda algısal olarak izlemeyi kolaylaştırmak açısından başlığın teorik bir ders konusuna ait olduğu("Teor." şeklinde kısaltılmıştır) ve ders kodu gösterilmiştir.

8. Ders konusu için beklenen performans/öğrenme düzeyi kodu ve açıklaması; sistemde her ders konusu ve her portfolyo bileşeni için bir performans/öğrenme düzeyi belirlenmiştir. Elbette müfredatta yer alan tüm teorik dersler ve uygulamalar/pratikler gerekli ve değerlidir. Fakat Ulusal Çekirdek Eğitim Programı(ÇEP)'nda da belirtildiği gibi hem teorik dersler hem de uygulamalar için farklı performans/öğrenme düzeyleri belirlenmiştir. $\mathrm{Bu}$ düzeylere göre bazı derslere veya becerilere öncelik ve önem verilmesi gerektiği vurgulanmıştır. Projede geliştirilen bu sistemde teorik derslere ilişkin iki farklı performans/öğrenme düzeyi sınıflaması yapılmış ve 
tüm ders konularına yansıtılmıştır. Eğer teorik ders konusu içeriği doğrudan bir hastalık veya klinik problem şeklindeyse (ör. Demir Eksikliği Anemisi) bu ders konusuna aşağıdaki performans/öğrenme düzeyi sınıflama tablosundan bir düzey atanmıştır (Tablo 1).

Sistemde Tablo 1'deki bu performans/öğrenme düzeyleri şu şekilde kodlanmıștır; ör. HKLPR-1 2. Bunun anlamı; bu teorik ders konusu içeriği bir hastalık veya klinik probleme yöneliktir, bu ders konusuna ilişkin beklenen performans/öğrenme düzeyi 1 ve 2 'dir (1: Acil durumu tanımlar, acil tedavisini yapar, gerektiğinde uzmana yönlendirir. 2: Ön tanı koyar, ön işlemleri yapar, uzmana yönlendirir.). Hastalık veya klinik problem içerikli bir ders konusuna HKLPR performans kodlarından birden fazla atanabilmektedir. $\mathrm{Bu}$ düzeyler mutlak sinırları belirtmemekle birlikte ders konusunun niteliği, önceliği veya önemine ilişkin fikir vermek amacıyla sisteme entegre edilmiştir. Eğer teorik ders konusunun içeriği doğrudan bir hastalık veya klinik probleme yönelik değilse (ör. Hümoral İmmünitenin Efektör Mekanizmaları) bu durumda ders konusuna Tablo 2'deki performans/öğrenme düzeylerinden biri atanmaktadir.

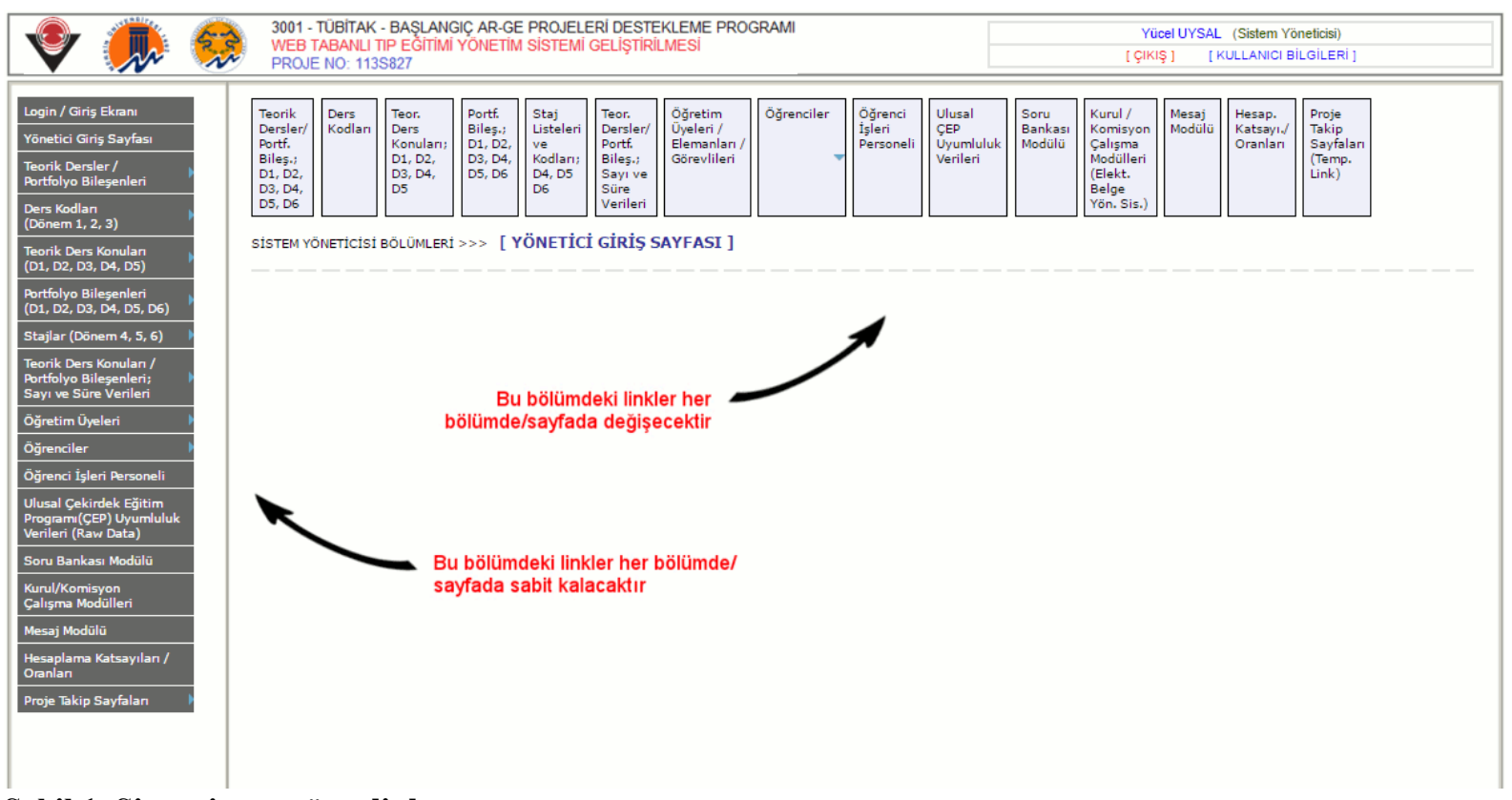

Şekil 1. Sistemin menü ve link yapısı

\begin{tabular}{|c|l|l|}
\hline $\begin{array}{l}\text { Tablo 1. İçeriği doğrudan bir hastalık veya klinik problem olan teorik derslere atanacak } \\
\text { performans/öğrenme/yeterlik düzeyleri }\end{array}$ \\
\hline $\begin{array}{l}\text { Yönetim } \\
\text { sistemindeki } \\
\text { kod }\end{array}$ & $\begin{array}{l}\text { Ulusal } \\
\text { ÇEP'deki } \\
\text { kod }\end{array}$ & Açıklaması \\
\hline 1 & $\mathrm{~A}$ & $\begin{array}{l}\text { Acil durumu tanımlar, acil tedavisini yapar, gerektiğinde uzmana } \\
\text { yönlendirir. }\end{array}$ \\
\hline 2 & ÖnT & Ön tanı koyar, ön işlemleri yapar, uzmana yönlendirir. \\
\hline 3 & $\mathrm{~T}$ & $\begin{array}{l}\text { Tanı koyabilir, tedavi hakkında bilgi sahibi olur, ön işlemleri yapar, } \\
\text { uzmana yönlendirir. }\end{array}$ \\
\hline 4 & $\mathrm{TT}$ & Tanı koyar, tedavi eder. \\
\hline 5 & $\dot{\mathrm{I}}$ & Birinci basamak şartlarında uzun süreli takip(izlem) ve kontrolünü yapar. \\
\hline 6 & $\mathrm{~K}$ & $\begin{array}{l}\text { Korunma önlemlerini(birincil, ikincil ve üçüncül korunmadan uygun } \\
\text { olan/olanları) uygular. }\end{array}$ \\
\hline
\end{tabular}




\begin{tabular}{|c|l|}
\hline $\begin{array}{l}\text { Tablo 2. İçeriği doğrudan bir hastalık veya klinik problem olmayan teorik derslere atanacak } \\
\text { performans / ögrenme / yeterlik düzeyleri }\end{array}$ \\
\hline Yönetim sistemindeki kod & Açıklaması \\
\hline 1 & 6 üzerinden $1(\% 16,5)$ \\
\hline 2 & 6 üzerinden $2(\% 33)$ \\
\hline 3 & 6 üzerinden $3(\% 49,5)$ \\
\hline 4 & 6 üzerinden $4(\% 66)$ \\
\hline 5 & 6 üzerinden $5(\% 82,5)$ \\
\hline 6 & 6 üzerinden $6(\% 100)$ \\
\hline
\end{tabular}

Tablo 2'de vurgulanan performans/öğrenme düzeylerinin amac1 o ders konusunun önemini veya önceliğini belirlemek veya ders konularını bu parametreye göre siralayabilmektir. Sistemde bu şekilde belirtildiği halde daha sonra istendiği takdirde bu düzeylere ilişkin ifadeler değiştirilebilir veya örneğin altı üzerinden bir sınıflama yerine on üzerinden bir sınıflama da sisteme entegre edilebilir. $\mathrm{Bu}$ parametrenin müfredat içeriğini planlarken ders konularına ayrılacak süreleri belirlemede veya diğer farklı planlamalar sırasında kullanılabileceği öngörülmüştür.

9. Teorik ders konusunun sunulacağ

10. Ders konusunun dakika olarak süresi.

11. Ders konusunu sunacak olan eğitici öğretim üyesi.
12. İlgili ders konusuna ilişkin yazılı sınavda çıkacak tahmini soru sayıs1; bu say1 sistem tarafindan hesaplanmaktadır. Tüm ders konuları girildikten sonra sistem ders konularının toplam sayısını ve süresini hesaplamaktadır. Soru bankası modülü üzerinde ders kurulu veya staj yazılı sinavı hazırlanırken ders konularına ilişkin sayı ve süreler soru bankası tarafindan çekilmektedir. Sınavda toplam kaç soru sorulacağı bilgisi girildiğinde toplam soru sayısı konu sayısı veya sürelerine göre paylaştırılmaktadır.

13. Bu bölümde yer alan son parametre teorik ders konusunun Ulusal ÇEP ile uyumluluk verisidir. Eğer bu ders başlığı Ulusal ÇEP içerisinde yer alıyorsa 1 (evet), yer almıyorsa 2 (hayır) değeri atanmaktadır.

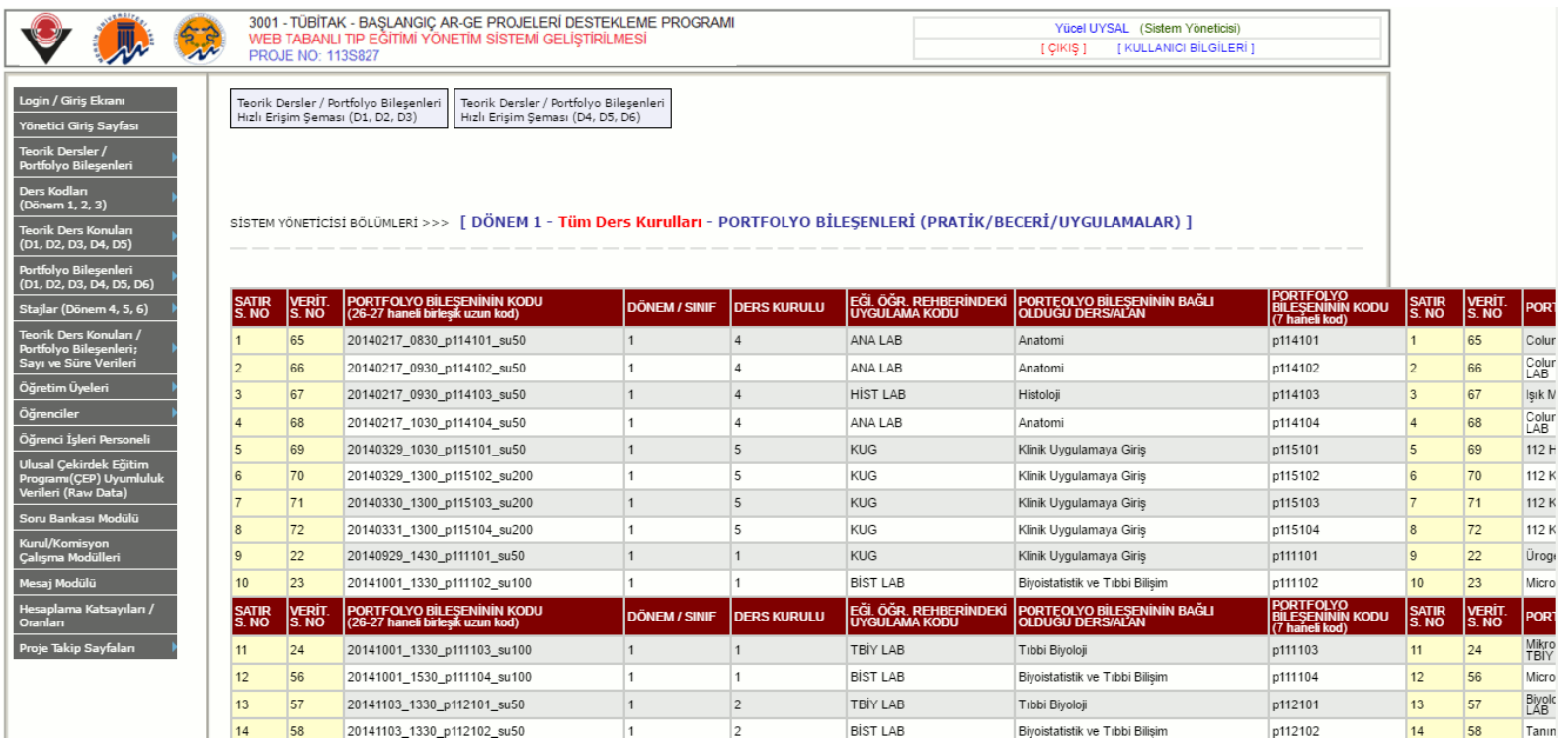

Şekil 2. Dönemlere, ders kurullarına ve stajlara göre ayrılmış portfolyo bileşenleri bölümleri

Şekil 2'de dönemlere, ders kurullarına veya stajlara göre listelenebilen portfolyo bileşenleri tablolarından bir örnek görülmektedir. Yukarıda sıralanan ders konuları parametrelerine ek olarak portfolyo bileşenlerinde şu parametreler yer almaktadir;

1. Portfolyo bileșeni süresinin yüzde olarak hangi oranda 'teorik' bilgi aktarılması, 'pratik/uygulama/beceri' yaptırılması ve 'iletişim' becerisini geliştirmeye yönelik olarak kullanıldığı bilgisi. Elbette bu oranları keskin sınırlar şeklinde belirleme imkanı yoktur. Bir becerinin geliștirilmesi ve örneğin klinik simülatör maketi üzerinde öğrencilere uygulama yaptırılması şeklinde planlanmış bir portfolyo bileşeninde pratik/uygulama oranı anlamlı şekilde yüksek olarak girilecektir. Öte yandan gerçekte bir portfolyo bileşeni uygulama/beceri/pratik olarak planlanmış olmasına rağmen o sürenin büyük çoğunluğu öğrencilere o konuda teorik ilgi aktarımı ile geçirilmiş olabilir. Tahmini olarak bu verilerin önceden planlanarak girilmesi veya portfolyo çalıșmaları sonrası tahmini olarak girilmesinin ardından sistem tüm bu portfolyo sürelerine ilişkin 
hesaplamalar sırasında toplam sürelerinin bu üç başlığa dağılımını da analiz edecektir. Buna göre toplam portfolyo süresinin hangi oranlarda teorik, pratik ve iletişim becerilerine yönelik harcandığ1 verisi elde edilmiş olacak, gerek görülürse ortaya çıkan dengesiz dağılımın giderilmesine yönelik düzenlemeler yapılabilecektir.

2. Portfolyo bileşeni çalışması öncesi öğrencilerin erişimine açılacak çalışma dokümanı adı ve bağlantısı; her portfolyo bileşeni için ilgili bölüm veya eğitici öğretim üyeleri tarafından hazırlanmış çalışma dokümanı sisteme yüklenecek ve öğrencilerin ve öğretim üyelerinin erișimine açılacaktır. Öğrencilerin portfolyo çalışması öncesi bu dokümanlara göz atma ve ön hazırlık yapma şansları olacaktır. İnternet erişimi olan her yerden ulaşılabilecek bu dokümanlar sayesinde gerçekleştirilecek ön hazırlığın ilgili portfolyo bileşeni çalışmasının daha verimli geçmesine, öğrencilerin çalışma öncesi en azından konuyla ilgili farkındalık kazanmasına faydası olacağı öngörülmektedir. Bu dosyalar yetki verilmiş öğretim üyeleri tarafindan sisteme yüklenebilecek ve güncellenebilecektir. Bu çalışma dokümanlarının sistem üzerinde yer alması zaman içinde ilgili bölüm veya öğretim üyelerinin bu dokümanları güncellemelerini de kolaylaştıracaktır.

3. Öğrencilerin portfolyo bileşeni çalışması öncesi ön hazırlı dokümanına göz atması/okuması/çalışması için gerekli tahmini süre; bu sürelerin toplamda hesaplanmasının en azından portfolyo çalışmalarına ilişkin fakülte dışında öğrencilerin eğitim öğretim faaliyetlerine ne kadar zaman ayırdıklarının küçük bir göstergesi olacağ 1 öngörülmektedir. Gerçekte bu süreleri kesin olarak tahmin etmek mümkün değildir. Fakat örneğin dönem 1'in birinci ders kurulu için müfredatta ve sistem üzerinde 15 portfolyo bileşeni tanımlanmış ise ve her bir portfolyo bileşeni için ön hazırlık çalışma süresi olarak 15 dakika tahmin ediliyorsa, toplamda öğrencilerin fakülte dışında 225 dakikayı portfolyo ön hazırlık çalışmalarına harcaması sağlanmış olacaktır. Elbette öğrenciden öğrenciye değişmekle beraber, bazı öğrenciler daha uzun vakit ayırabilirken bazı öğrenciler de ön hazırlık dokümanlarına hiç bakmadan portfolyo çalışmasına gelebilirler. Öğrencilerin ön hazırlık yapıp yapmadığ 1 da eğiticiler tarafından portfolyo çalışması sırasında değerlendirilebilir. $\mathrm{Bu}$ da portfolyo çalışması notlarını verirken eğitici için göz önünde tutulmas1 gereken bir nokta olabilir.

4. Portfolyo bileşeni için öngörülen performans/öğrenme düzeyi kodu ve açıklaması; teorik dersler için belirlenen performans/öğrenme düzeyine benzer şekilde portfolyo çalışmaları için de sistem üzerinde bir düzey atanmıştır. Burada kullanılan performans/öğrenme düzeyleri Ulusal Çekirdek Eğitim Programı dokümanından alınmıştır. Tablo 3'de bu performans/öğrenme/yeterlik düzeyleri gösterilmiştir.

\begin{tabular}{|c|l|}
\hline Tablo 3. Portfolyo bileşenlerine atanacak performans/öğrenme/yeterlik düzeyleri \\
\hline $\begin{array}{l}\text { Performans/öğrenme/ } \\
\text { yeterlik düzeyi }\end{array}$ & Açıklaması \\
\hline 1 & $\begin{array}{l}\text { Uygulama hakkında bilgi sahibidir, nasıl yapıldığını ve sonuçlarını } \\
\text { açıklayabilir. }\end{array}$ \\
\hline 2 & Acil durumda uygulamayı yapar. \\
\hline 3 & Karmaşık olmayan, sık görülen durumlarda uygulamayı yapar. \\
\hline 4 & Karmaşık durumlar da dahil uygulamayı yapar. \\
\hline
\end{tabular}

Her bir portfolyo bileşenine sadece bir tane performans/yeterlik düzeyi atanmıştır. $\mathrm{Bu}$ düzey portfolyo bileşeninin önceliği ve önemi hakkında fikir verecektir. Özellikle yüksek performans/yeterlik düzeyine sahip (düzey 4) portfolyo çalışmalarına ilişkin başarı değerlendirmeleri düşük olan öğrencilerde bu durumun telafi edilmesi ve bu portfolyo bileşenlerine ilişkin öğrenciye ek eğitim öğretim imkanı sağlanması gibi düzenlemeler planlanabilir. Ayrica not hesaplamaları yapilırken portfolyo not ortalamaları ağırlıklı ortalama şeklinde hesaplanmaktadır; düzey 4 olan bir portfolyo bileşeninden alınan notun ortalamaya etkisi düzey l'e kıyasla daha daha fazla olacaktır.
'Teorik Ders Konuları / Portfolyo Bileşenleri Sayı ve Süre Verileri' Bağlantısı/Bölümü

$\mathrm{Bu}$ bölümde teorik ders veya portfolyo çalışmaları açısından eğitim öğretim faaliyetlerine katılan öğretim üyelerinin hangi dersleri verdiği, hangi portfolyo bileşenleri çalışmalarına katkı sağladığı, bunlara ilişkin sayı ve süre verileri yer almaktadır. Yine öğretim üyeleri bazlı hesaplamalar sonucu bölüm/anabilim dalına göre de ders veya portfolyo sayıları ve sürelerini takip etmek mümkündür. $\mathrm{Bu}$ bölümdeki hesaplama algoritmaları tüm veri tabanındaki ilişkili tüm tabloları tarayarak öğretim üyeleri ve anabilim dallarına göre verileri derlemektedir. O yüzden farklı alanlarda ders ekleme, ders çıkarma, portfolyo bileşeni ekleme 
veya çıkarma gibi değişikliklerden sonra buradaki hesaplama bağlantısı aracılığı ile verilerin yeniden hesaplanması gerekmektedir. Hesaplama işlemi yaklaşık 5-6 dakika süren bir işlemdir. Sistem her gece 02:00-04:00 arasında bu tür gücellemeleri ve hesaplamaları otomatik olarak yapmaktadır. Fakat gün içerisinde yapılan bazı değişikliklere ilişkin yeni çıktıların hemen görülmesi istendiğinde buna benzer hesaplama işlemlerini manuel olarak yapmak gerekmektedir. Şekil 3'de öğretim üyeleri bazında tüm teorik ders ve portfolyo çalışması verileri görülmektedir. Her öğretim üyesinin kaçınc1 dönemde, kaçıncı ders kurulu veya stajda kaç tane teorik ders veya portfolyo oturumuna katkıda bulunduğu ve bu çalışmalara ilişkin süreler tabloda görülmektedir. Şekil 4'de anabilim dalı/bölüm bazında teorik ders ve portfolyo çalışmalarına ilişkin veriler görülmektedir.

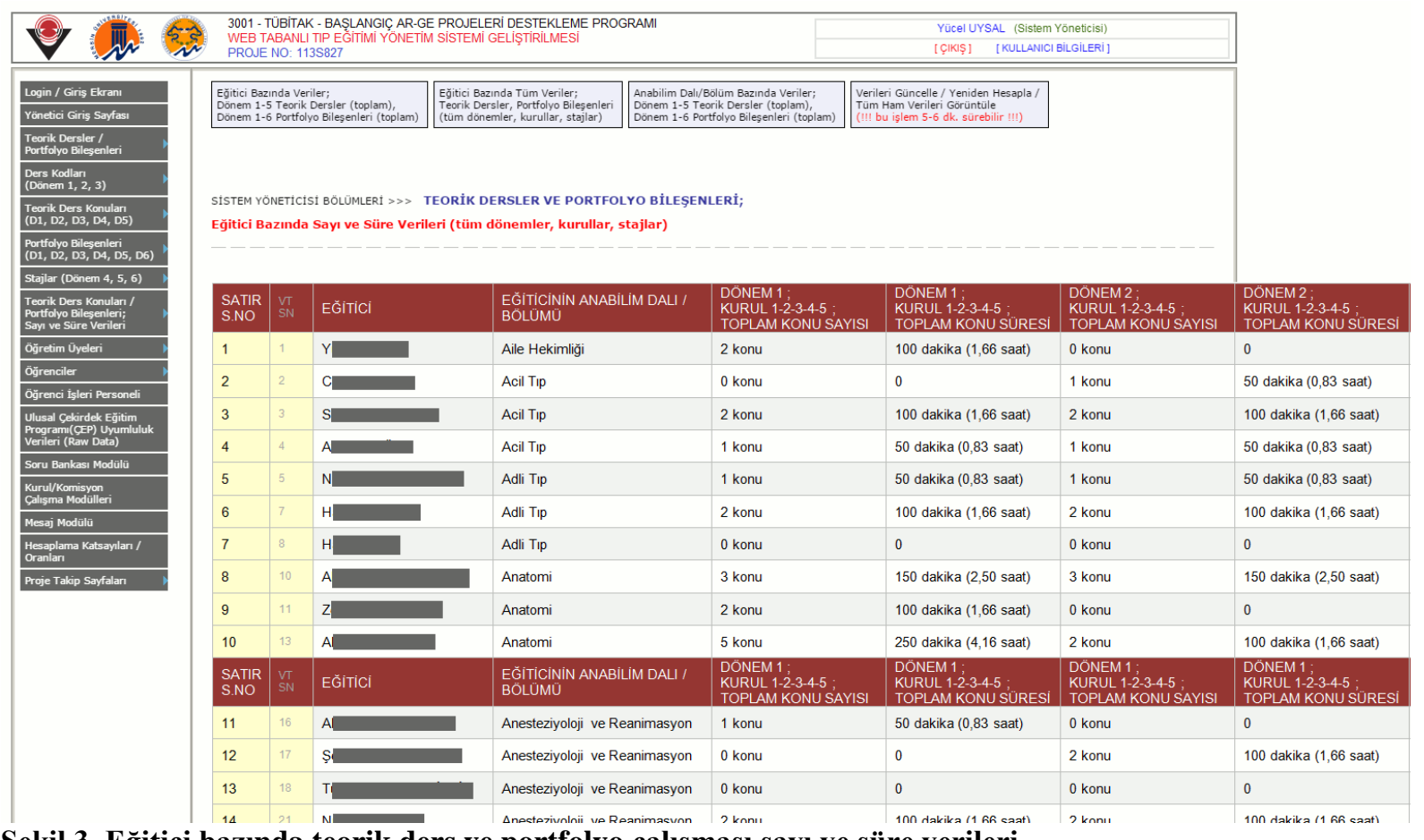

Şekil 3. Eğitici bazında teorik ders ve portfolyo çalışması sayı ve süre verileri

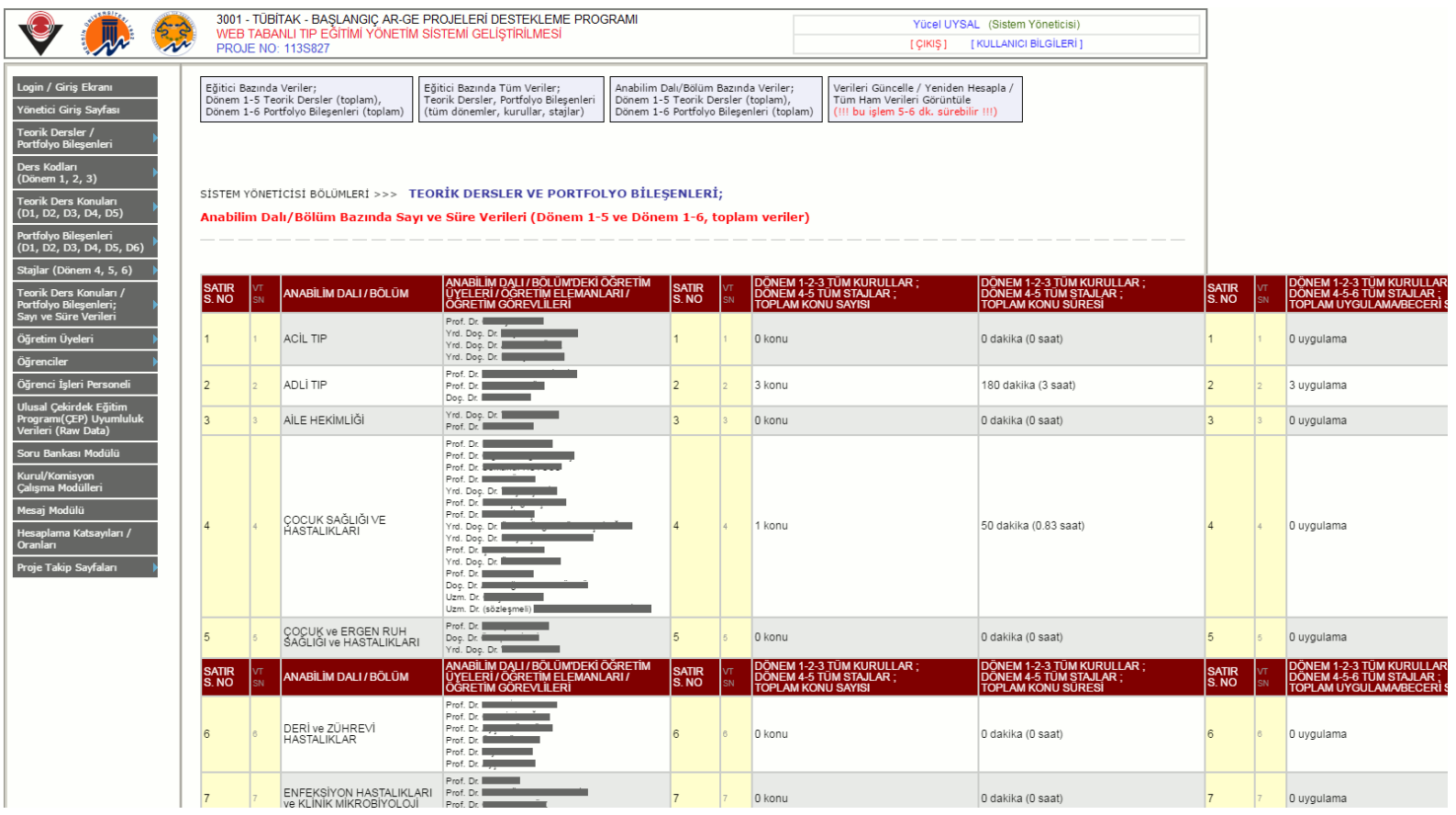

Şekil 4. Anabilim dalı/bölüm bazında teorik ders ve portfolyo çalışması sayı ve süre verileri 


\section{'Öğrenciler' Bağlantısı/Bölümü}

Öğrenci listelerine dönemlere ve stajlara göre erişim mümkündür. Diğer arayüzlerde olduğu gibi hem temel verilere ilişkin tablolar hem de kapsamlı ve ayrıntılı tablolar mevcuttur.Öğrenciler bağlantısı altındaki diğer önemli bölüm öğrencilere ilişkin başarı değerlendirme verileridir. Şekil 5'de dönem 1 öğrencilerine ait portfolyo bileşenleri notları görülmektedir.

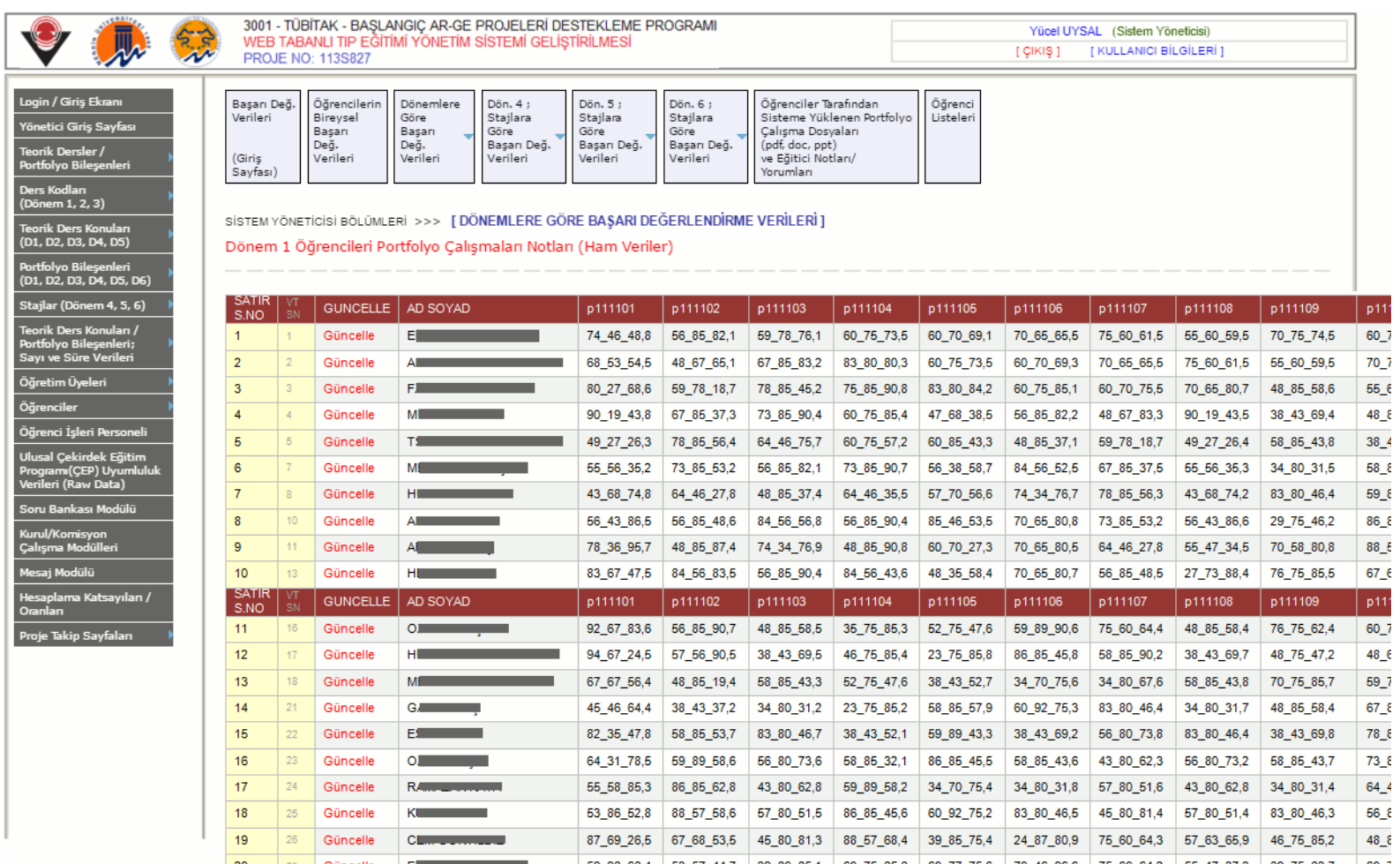

Şekil 5. Portfolyo bileşenleri notları (Dönem 1 öğrencileri, ham veriler)

$\mathrm{Bu}$ ham verilerin olduğu bir tablodur. Hesaplama ve analizler ham veri tablolarına dayalı olarak yapılmaktadır. $\mathrm{Bu}$ tabloda sağa doğru ilerleyen kolonlarda birinci sınıftaki tüm portfolyo bileşenleri yer almaktadır. Portfolyo kodları p111101'den başlamaktadır. Bu kodlar daha önce anlatılan portfolyo kodları ile aynıdır. Kodu oluşturan bileşenler;

$\mathrm{p}$ : portfolyo

$1:$ dönem 1 ,

11 : birinci ders kurulu

101 : 101 nolu portfolyo bileşeni (hem teorik ders kodları hem de portfolyo bileşenleri 101 ile başlamaktadır)

Şekil 5'de yer alan üç nottan birincisi

Böylece öğrenci özellikle öncelikli/önemli portfolyo çalışmalarından yüksek notlar aldığında veya düşük notlar aldığına bu notlar ortalamayı daha çok etkileyecektir.

Sistemde bazı oranlar, katsayılar ve koşullar değiştirilebilmektedir. Yapılan değişiklikler tüm sistemin hesaplama altyapısını, tablo düzenlerini ve kritik pek çok algoritmanın akışını öğrencinin portfolyo çalışmasına ilişkinin ön testte aldığı nottur. İkinci not eğiticinin portfolyo çalışması için öğrenciye verdiği nottur. $\mathrm{Bu}$ notlardan birincisinin \%10'u ile ikincinin \%90'1 toplanarak portfolyo sonuç notu hesaplanmaktadır. Böylece her öğrenci için ders kurulundaki portfolyo çalışmalarından bir 'portfolyo sonuç notu' hesaplanmaktadır. $\mathrm{Bu}$ oranlar senaryo gereği belirlenmiș oranlardır. İstendiği takdirde bu oranlar ve katsayılar değiştirilebilmektedir. Daha sonra ders kurulu içinde alınmış olan portfolyo sonuç notları portfolyoların performans/yeterlik düzeyleri ağırlığına göre hesaplanarak "ders kurulu sonu ortalama portfolyo notu" belirlenmektedir. $\mathrm{Bu}$ hesaplamaya ilişkin örnek senaryo Tablo 4'de gösterilmiştir.

değiştirdiği için eğitim öğretim dönemi tamamlandıktan sonra yapılmalıdır. Değişiklikler her dönem (sınıf) için ayrı ayrı girilmektedir. Bu işlem sırasında veri tabanı diğer kullanıcıların erişimine kapatılacağı için bu konuda kullanıcılar uyarılmalı ve işlem sırasında tüm sistem askıya alınmalıdır. 


\begin{tabular}{|c|c|c|c|c|c|}
\hline $\begin{array}{l}\text { p11101 notu } \\
\text { (performans } \\
\text { düzeyi: 1) }\end{array}$ & $\begin{array}{l}\text { p11102 notu } \\
\text { (performans } \\
\text { düzeyi: } 3 \text { ) }\end{array}$ & $\begin{array}{l}\text { p11103 notu } \\
\text { (performans } \\
\text { düzeyi: } 2 \text { ) }\end{array}$ & $\begin{array}{l}\text { p11104 notu } \\
\text { (performans } \\
\text { düzeyi: } 4 \text { ) }\end{array}$ & $\begin{array}{l}\text { p11105 notu } \\
\text { (performans } \\
\text { düzeyi: } 1 \text { ) }\end{array}$ & $\begin{array}{l}\text { performans } \\
\text { düzeyleri(katsayılar) toplamı: } \\
1+3+2+4+1=11\end{array}$ \\
\hline 80 & 58 & 68 & 55 & 86 & $\begin{array}{l}\text { eşit ağırlıklı ortalama: } \\
80+58+68+55+86=347 \\
347 / 5=69,4 \\
69,4\end{array}$ \\
\hline $\begin{array}{l}\text { kat. }=1 / 11= \\
0,09\end{array}$ & $\begin{array}{l}\text { kat. }=3 / 11= \\
0,27\end{array}$ & $\begin{array}{l}\text { kat. }=2 / 11= \\
0,18\end{array}$ & $\begin{array}{l}\text { kat. }=4 / 11= \\
0,36\end{array}$ & $\begin{array}{l}\text { kat.= } \mathbf{1 / 1 1}= \\
0,09\end{array}$ & $\begin{array}{l}\text { performans düzeyine göre } \\
\text { ağırlıklı ortalama: }\end{array}$ \\
\hline $\begin{array}{l}80 \times 0.09= \\
7,2\end{array}$ & $\begin{array}{l}58 \times 0,27= \\
15,6\end{array}$ & $\begin{array}{l}68 \times 0,18= \\
12,2\end{array}$ & $\begin{array}{l}55 \times 0,36= \\
19,8\end{array}$ & $\begin{array}{l}86 \times 0,09= \\
7,7\end{array}$ & $\begin{array}{l}7,2+15,6+12,2+19,8+7,7= \\
\mathbf{6 2 , 5}\end{array}$ \\
\hline
\end{tabular}

\section{Ulusal ÇEP ile Uyum}

Bu bölümde teorik ders başlıkları ve içeriklerinin, portfolyo bileşenleri(beceri/uygulama/pratikler) başlıkları ve içeriklerinin Ulusal ÇEP ile ne düzeyde örtüştüğüne dair fikir verebilecek verilerin çıktıları izlenebilir. Daha önceki bölümlerde bahsedildiği üzere her teorik ders ve portfolyo bileşeni yapılandırılırken ve verileri sisteme girilirken Ulusal ÇEP ile uyumuna dair bir parametrede giriliyordu. Varsayılan haliyle sistemde bu veri 1(evet) ve 2(hayır) olarak girilmektedir. Bu modüle ilişsin hesaplama altyapısı sisteme entegre edildiği için ilerleyen zamanlarda istenirse evet/hayır yerine bir yüzde (ör. $\% 45$ gibi) veya örneğin 5 'li veya $10^{\prime} l u$ likert ölçeğinde ilgili başlı̆̆ın ÇEP ile uyumu belirtilebilir.

\section{'Soru Bankası Modülü' Bölümü}

Projenin en kapsamlı ve zorlayıcı modülü soru bankası modülü olmuştur. Öngörülenden çok daha fazla sorunla karşılaşılmış, özellikle ayrıntılı istatistiksel analizler konusunda farklı ögretim üyelerinden katkı ve destek alınmıştır. Tüm sorunlara rağmen proje başlangıcında hedeflenenden çok daha kapsamlı ve işlevsel bir modül gerçeklenmiştir.

Soru bankası modülü sistemle entegre çalıştığı halde 'giriş/login' basamağ 1 sistemden ayrı olarak tasarlanmıştır. Sistem üzerindeki 'Soru Bankası Modülü' bağlantısına tıklandığında ayrı bir pencerede tekrar 'giriş/login' arayüzü açılmaktadır. Soru bankası modülünde güvenlik kritik bir nokta olduğu için 'kullanıcı adı' ve 'şifre' doğrulamalarına ek olarak bu modüle ayrıca kısa mesaj servisi(sms) doğrulama algoritması da eklenmiştir.

'Dersler' bağlantısı altında soru bankasına aktarılmış ve ilgili sınavda soru çekilecek olan ana ders başlıkları görülmektedir. Sistemdeki tüm ana ders başlıkları otomatik olarak soru bankasına entegre edilmemiştir. Çünkü düzenlenecek teorik sinavlarda soru çekme, soru analizleri ve cevap analizlerine katılmayacak ders başlıkları olabileceği öngörülerek bu işlem otomatik olarak yürütülecek şekilde yapılandırılmamıştır. O yüzden ders, konu ve alt konu olarak hangi derslerin soru bankasına aktarılacağı kullanıcılar tarafindan kolay bir işlemle sağlanmaktadır. Her konudan kaç soru çıkacağı bilgisi müfredat takip alt modüllerinde tanımlanmıştır. Fakat istendiği takdirde sınavda konulardan ve alt konulardan çıkacak soru sayıları soru bankası modülü üzerinden tekrar değiştirilebilmektedir.

Konular bağlantısı altında tüm konulara ilişkin veri tablosu, derslere sınıflanmış konu listeleri ve yeni konu/alt konu ekleme bölümleri bulunmaktadır.

Sorular bölümünde; soruların yönetimi, incelenmesi, düzeltilmesi gibi işlemler yapılmaktadır. Sorular bağlantısı altındaki 'listele' alt linkine tıklandığında ana soru tablosu açılmaktadır. $\mathrm{Bu}$ tablo üzerinde şu veriler ve işlevler mevcuttur;

1. Sorunun sira numarasi.

2. Sorunun veri tabanı id numarası.

3. Soruyu ekleyen/gönderen öğretim üyesi bilgisi.

4. Sorunun eklenme tarihi.

5. Sorunun güncellenme tarihi.

6. Sorunun hangi ders altında yer aldığı verisi.

7. Sorunun hangi konu altında yer aldığı verisi.

8. Soru metni.

9. Soruya ilişkin soru kitapçığında yer alacak görsel/imaj/şekil/resim.

10. Sorunun hedefi; analizlerde kullanılmak üzere soru yapısının hangi hedefe yönelik olarak yapılandırıldığı bilgisi. Varsayılan olarak şu hedefler tanımlanmıştır; hatırlama, analiz, anlama, değerlendirme, uygulama, yaratma.

11. Sorunun cevap seçenekleri ve cevap metinleri; bu alanda ayrıca sorunun doğru seçeneği de belirtilmiştir.

12. Sorunun kaç defa güncellendiği bilgisi.

13. Sorunun zorluk derecesi.

14. Sorunun kaç defa yayınlandığı (sorunun kaç sinavda kullanıldığı).

'Sorular' bağlantısı altında, derslere ve 


\begin{tabular}{|l|l|l|}
\hline \multicolumn{3}{|l|}{ Tablo 5. Soru havuzundan derslere göre soru çekilmesi } \\
\hline Dersler & $\begin{array}{l}\text { Kurul içindeki } \\
\text { toplam ders süreleri }\end{array}$ & $\begin{array}{l}\text { Herbir ders için soru havuzundan } \\
\text { rastgele alınacak soru sayısı }\end{array}$ \\
\hline İç Hastalıkları & 36 saat & 63 \\
\hline Biyoistatistik ve Tibbi Bilişim & 13 saat & 22 \\
\hline Tip Tarihi ve Etik & 9 saat & 15 \\
\hline Toplam süre & 58 saat & \\
\hline Toplam soru sayıs1 & 100 \\
\hline
\end{tabular}

*(sınavda toplam 100 soru yer alacağı varsayılmıştır)

\begin{tabular}{|l|l|l|l|}
\hline \multicolumn{2}{|l|}{ Tablo 6. Soru havuzundan konulara göre soru çekilmesi } \\
\hline \multirow{2}{*}{ Dersler } & Konular & $\begin{array}{l}\text { Konuların kurul içindeki } \\
\text { toplam süreleri }\end{array}$ & $\begin{array}{l}\text { Her bir konu için soru } \\
\text { havuzundan rasgele alınacak } \\
\text { soru sayıs1 }\end{array}$ \\
\hline \multirow{2}{*}{ İç Hastalıkları } & Solunum sistemi hastalıkları & 14 saat & 25 \\
\cline { 2 - 4 } & İskemik kalp hastalıkları & 22 saat & 38 \\
\hline $\begin{array}{l}\text { Biyoistatistik ve } \\
\text { T1bbi Bilişim }\end{array}$ & Hipotez testleri & 8 saat & 14 \\
\cline { 2 - 4 } $\begin{array}{l}\text { Tip Tarihi ve } \\
\text { Etik }\end{array}$ & Örneklem yöntemleri & 5 saat & 8 \\
\cline { 2 - 4 } & Hint ve Çin tıbbı & 6 saat & 10 \\
\hline Toplam süre & 3 saat & 5 \\
\hline \multicolumn{2}{|l|}{ Toplam soru sayıs1 } & 58 saat & 100 \\
\hline
\end{tabular}

*(sınavda toplam 100 soru yer alacağı varsayılmıştır)

\begin{tabular}{|c|c|c|c|c|}
\hline Ders & Konu & Alt konu & $\begin{array}{l}\text { Alt konuların } \\
\text { süreleri }\end{array}$ & $\begin{array}{l}\text { Her bir alt konu } \\
\text { için çekilecek } \\
\text { soru sayısı }\end{array}$ \\
\hline \multirow{4}{*}{ İç Hastalıkları } & \multirow{2}{*}{$\begin{array}{l}\text { Solunum sistemi } \\
\text { hastalıkları }\end{array}$} & $\begin{array}{l}\text { Solunum sistemi } \\
\text { enfeksiyonları }\end{array}$ & 8 saat & 14 \\
\hline & & $\begin{array}{l}\text { Obstrüktif akciğer } \\
\text { hastalıkları }\end{array}$ & 6 saat & 11 \\
\hline & \multirow{2}{*}{$\begin{array}{l}\text { İskemik kalp } \\
\text { hastalıkları }\end{array}$} & Anjina pektoris & 14 saat & 25 \\
\hline & & Akut myokard iskemisi & 8 saat & 13 \\
\hline \multirow{4}{*}{$\begin{array}{l}\text { Biyoistatistik ve } \\
\text { T1bbi Bilişim }\end{array}$} & \multirow{2}{*}{ Hipotez testleri } & $\begin{array}{l}\text { Bağımsız grup } \\
\text { ortalamalarına ilişkin testler }\end{array}$ & 5 saat & 8 \\
\hline & & $\begin{array}{l}\text { Bağımlı grup ortalamalarına } \\
\text { ilişkin testler }\end{array}$ & 3 saat & 6 \\
\hline & \multirow{2}{*}{$\begin{array}{l}\text { Örneklem } \\
\text { yöntemleri }\end{array}$} & Basit seçkisiz örnekleme & 1 saat & 2 \\
\hline & & Tabakalı örnekleme & 4 saat & 6 \\
\hline \multirow{4}{*}{ Tip Tarihi ve Etik } & \multirow{2}{*}{ Tip evrimi } & Türkiye'de tıp evrimi & 2 saat & 4 \\
\hline & & Dünyada tıp evrimi & 4 saat & 6 \\
\hline & \multirow[b]{2}{*}{ Hint ve Çin tıbbı } & Hint ve Çin tıbbının kökeni & 2 saat & 3 \\
\hline & & $\begin{array}{l}\text { Hint ve Çin tıbbının } \\
\text { günümüzdeki uygulamaları }\end{array}$ & 1 saat & 2 \\
\hline \multicolumn{3}{|l|}{ Toplam süre } & 58 saat & \\
\hline \multicolumn{4}{|l|}{ Toplam soru sayıs1 } & 100 \\
\hline
\end{tabular}

*(sınavda toplam 100 soru yer alacağı varsayılmıştır) 
konulara göre soru dağılımını gösteren bir arayüz de yer almaktadir.

Soru bankasından soru çekme yöntemi olarak nasıl bir yöntemin kullanılacağı; örneğin derse konu soru çekilecekse bu durumda belirlenen dersler, bu dersler altındaki konu sayıları, belirlenen toplam ders sayısı ve süresi, sınavda çıkacak toplam soru sayısı gibi veriler göz önüne alınarak bir hesaplama yapılacak ve hesaplamalar sonucuna göre derslerden soru çekilecektir. Eğer konuya göre soru çekilecekse bu durumda dersler altındaki konu sayıları, konu süreleri, sınavda toplam kaç soru olacağı gibi veriler göz önüne alınarak soru çekme işlemi gerçekleştirilecektir. Eğer konular içinde alt konular da belirlenmiş ve soru bankasına bu alt konulara göre soru girişleri yapılmışsa, bu durumda istendiği takdirde alt konulara göre soru çekimi yapılabilecektir. Bu durum örnek tablolar üzerinde özetlenmiştir (Tablo 5, 6, 7)

Görüldüğü gibi soru bankasına gönderilen sorular ders, konu ve alt konulara ayrilır ve herbir alt konudan mümkün olduğunca çok soru havuza gönderilirse sınavlarda birbirine benzer soru çıkma olasılığ1 azalacaktır. Hatta alt konularda birkaç alt başlığa ayrılabilirse (ör. yukarıdaki örnekte akut myokard iskemisi alt konusunun 'akut myokard iskemisinin belirtileri' ve 'akut myokard iskemisinde ilk basamak tanı ve tedavi yaklaşımları' şeklinde alt başlıklara ayrılması gibi) ve bu alt başlıklara ilişkin yeterli sayıda soru havuza gönderilebilirse daha sağlıklı çoktan seçmeli sınavlar düzenlenebilecektir. İşte tüm bu yöntemlerin uygulanabilmesi ve sonuçların analiz edilmesi kapsamlı özelliklerde bir dijital soru bankası ile mümkün olabilir.

Proje süresince dijital soru bankasına ilişkin proje ekibinin araştırmaları sonucu bu konuda ekip üyeleri bilgi ve tecrübelerini artırdıkça daha kapsamlı ve tüm bu fonksiyonları içeren dijital soru bankası yapılandırılması yoluna gidilmiştir. $\mathrm{Bu}$ durum proje süresinin yetersiz kalması ve proje için alınan desteğin yetersiz kalması gibi sorunlara yol açmış fakat ek tedbirler ve alternatif planlar sayesinde projenin tüm iş paketleri başarıyla tamamlanmıştır.

\section{Soru Bankası Modülü; 'İstatistikler' Bağlantısı/Bölümü}

$\mathrm{Bu}$ bağlantı altında yer alan alt bağlantılar/fonksiyonlar şunlardır; 1. Genel istatistikler, 2. İleri analizleri hazırlama, 3. Doğru sayısı grafiği, 4. Rjx analizini izleme, 5. Diğer analizleri izleme, 6. Rjx seçenek analizini izleme, 7. Diğer seçenek analizlerini izleme.

Bu analizlere ilişkin ekran görüntüleri Şekil 6 ve Şekil 7'de görülmektedir.

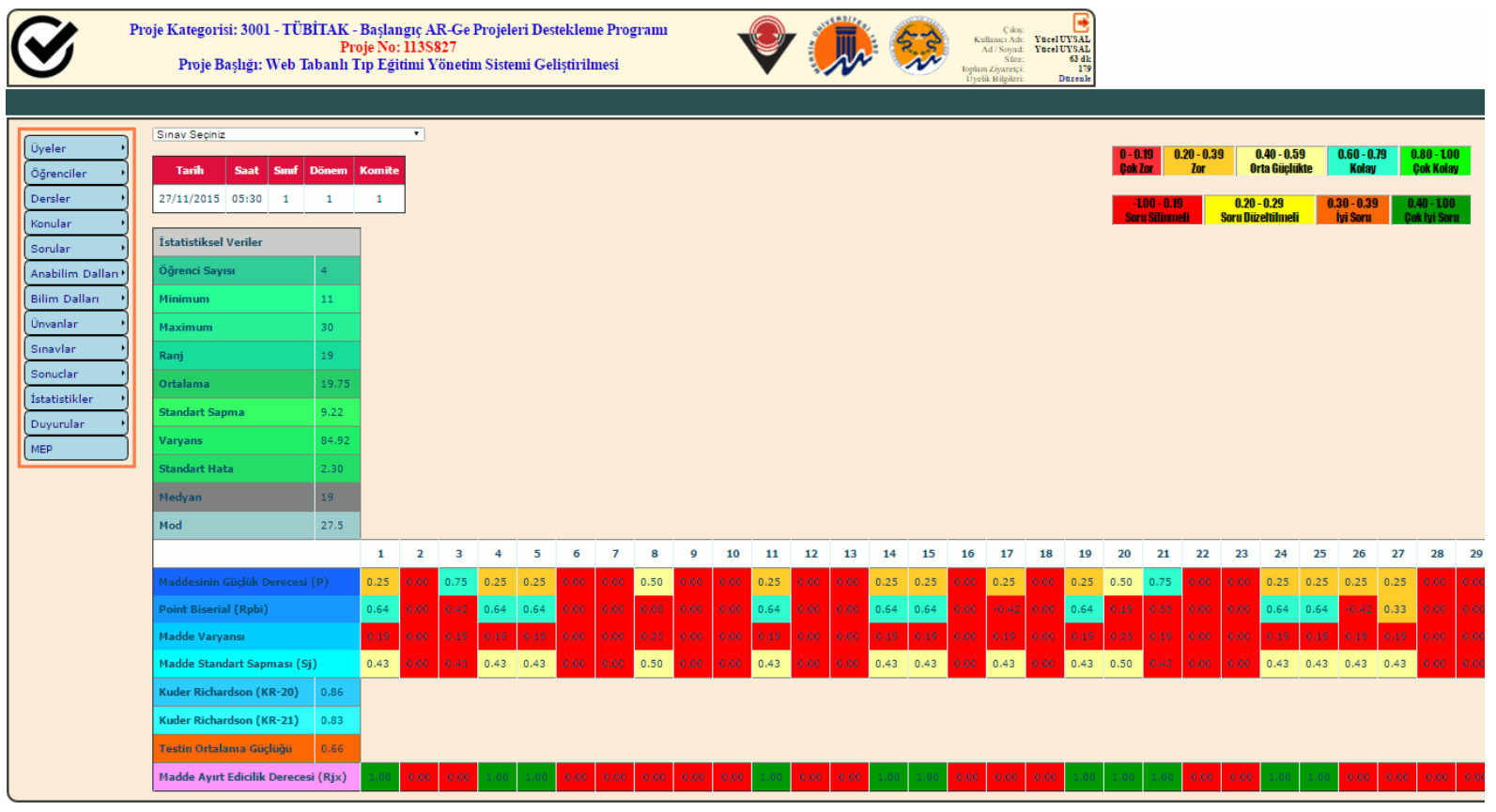

Şekil 6. Soru bankası modülü, 'istatistikler' bağlantısı; istatistiksel analiz ekranı 


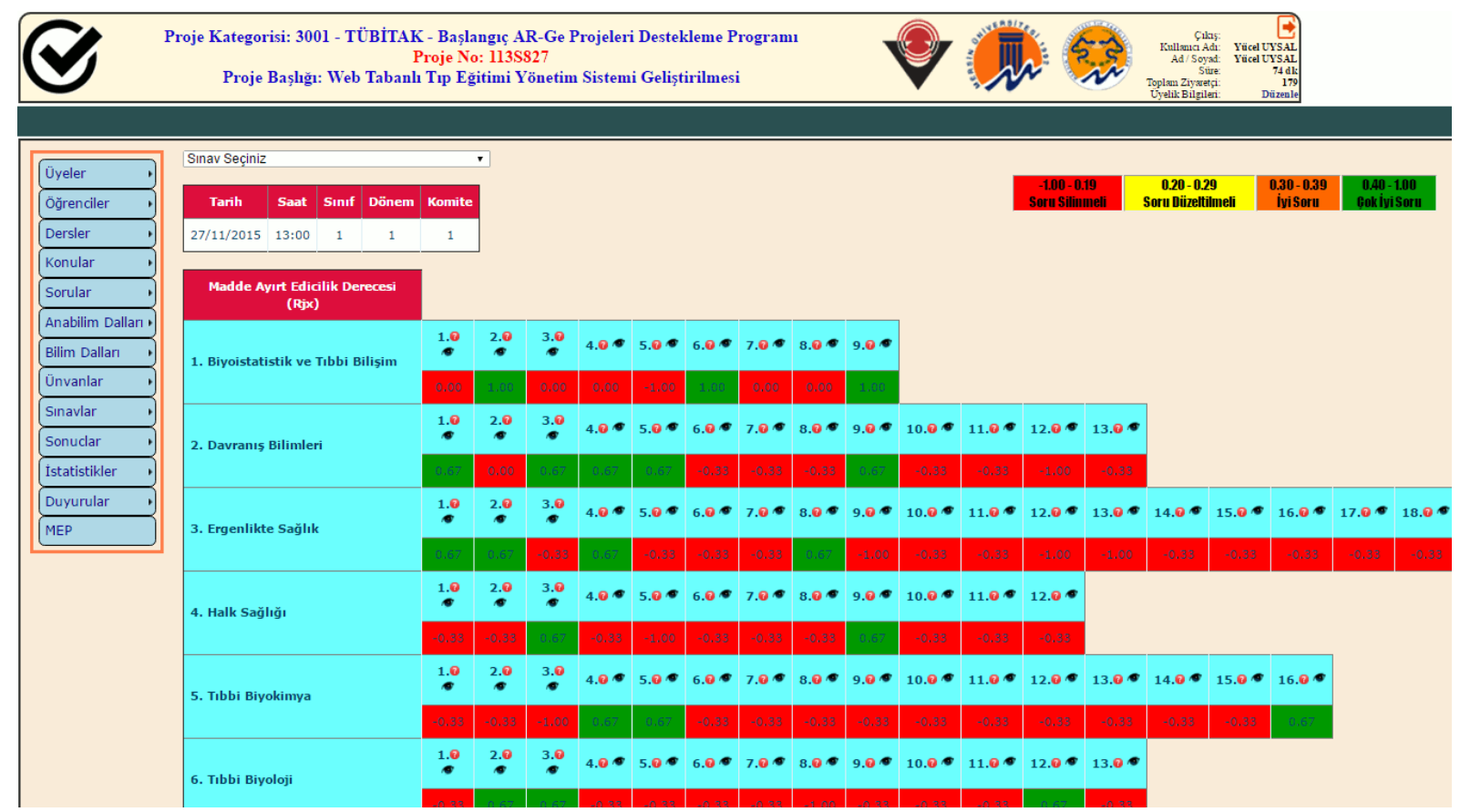

Şekil 7. Soru bankası modülü, 'istatistikler' bağlantısı; derslere göre madde ayırt ediciliği hesaplamaları

Bu bölümde elde edilen temel istatistiksel veriler şunlardır; 1. Öğrenci sayısı, 2. Minimum ve maksimum puanlar, 3. Aralık, 4. Ortalama, 5. Standart sapma, 6. Varyans, 7. Standart hata, 8. Medyan, 9. Mod.

Soru bankasının istatistik modülünde kullanılan ileri istatistiksel analizler ve anlamları şu şekilde özetlenebilir;

1. Madde güçlüğü; sorunun zorluğunu gösteren bir değerdir. 0 ve 1 arasında değer alır. 0 sorunun çok zor olduğunu ve 1 çok kolay olduğunu gösterir. Modülde bu değere ilişkin aralıklar şu şekilde belirlenmiş ve buna göre analizler yapılmıştır;

$$
\begin{aligned}
& * 0-0,19 \text { :çok zor } \\
& * 0,20-0,39: \text { zor } \\
& * 0,40-0,59 \text { :orta zorlukta } \\
& * 0,60-0,79: \text { kolay } \\
& * 0,80-1,00: \text { çok kolay }
\end{aligned}
$$

İdeal olan sinavda bu zorluk derecelerinde yaklaşık olarak benzer sayıda sorunun bulunmasıdır.

2. Rjx; madde ayırt edicilik indeksi. Madde ayırt ediciliği hakkında fikir verir. -1 ile +1 arasında bir değer alır. -1 değeri sorunun ayırt edici bir soru olmadığını ve soru havuzundan çıkarılması gerektiğini(sınavlarda kullanılmaması gerektiğini) gösterir. +1 değeri sorunun ayırt edicilik anlamında çok iyi bir soru olduğunu gösterir. Yapılandırılan bu modülde varsayılan olarak şu aralıklar belirlenmiştir;

$$
*-1,00-+0,19 \text { : soru bankadan }
$$
çkarılmalıdır

$$
\begin{aligned}
& *+0,20-+0,29: \text { bu soru düzeltilmeli } \\
& *+0,30-+0,39: \text { iyi soru } \\
& *+0,40-+1,00: \text { çok iyi soru }
\end{aligned}
$$

3. Rpbi ve Rbis; yine madde ayırt ediciliğini gösteren indekslerdir. Geliştirilen bu modülde altyapı olarak her ikisi de mevcuttur. Analiz çıktılarında Rpbi(Point Biserial) indeksi kullanılmaktadır. Aralık değerler ve yorumları Rjx gibidir.

4. Madde güçlük indeksi(P); yine sorunun zor mu kolay mı olduğunu gösteren bir indekstir.

5. Kuder Richardson KR-20 indeksi; testin güvenirliğini gösteren bir indekstir. 0 ve 1 arasında değer alır. $>=0,70$ ise testin güvenirliği yeterli düzeyde kabul edilir.

6. Kuder Richardson KR-21 indeksi; yine testin güvenirliğini gösteren bir indekstir. Değer aralıkları ve yorum KR-20 gibidir.

\section{SONUÇLAR VE TARTIŞMA}

Proje başlangıçta tasarlanan tüm modüllerle başarılı bir şekilde tamamlanmıştır. Özellikle soru bankası modülü başlangıçta öngörülenin çok ötesinde kapsamlı, detaylı ve işlevsel olmuştur. Projede, zaman ve bütçeyi denkleştirme konusunda zorluklar yaşanmıştır. Her ne kadar projenin ön hazırlık ve proje önerisi yazım aşamalarında yazılım iş paketlerini gerçekleyecek şirket ve yazılım uzmanlarıyla ayrıntılı görüşmeler yapıldıysa da, sistemdeki verilerin çeşitliliği, miktarı, veriler 
arasındaki karmaşık ilişkisel bağlantılar ve özellikle soru bankası modülündeki ayrıntılı ileri düzey istatistiksel hesaplamalar nedeniyle hem zaman olarak sıkışıklık yaşanmış hem de başlangıçta planlanan ve destek alınan bütçe öngörülenin üstünde aşılmıştır. Proje yürütücüsünün kişisel katkıları ile bütçe sorunu aşılabilmiş ve proje zamanında tamamlanmıştır. İş yükünün fazlalığı ve zaman kısıtlılığı nedeniyle geliştirilen sistemde ayrıntılı ve estetik görsel öğeler çok fazla kullanılamamıştır. Öncelik, fonksiyonel olarak doğru çalışan ve planlanan tüm modülleri içeren bir sistem geliştirilmesine verilmiştir.

Geliştirilen bu yönetim sisteminin, tıp eğitimine ilişkin pek çok farklı modülü bünyesinde toplaması ve bunları entegre şekilde çalıştırması sayesinde verimliliği artıracağı düşünülmektedir. Projede pratik/uygulama/beceri çalışmalarının her biri bir portfolyo bileşeni olarak ele alınmış ve her bileşene farklı parametreler eklenmesi sayesinde daha ayrıntılı analiz imkanı sağlanmıştır. En önemlisi sadece notlar ve müfredat programı bağlamında değil, ek olarak öğrencilerin serbest çalışma olarak yaptıkları portfolyo faaliyetlerinin tamamını dijital ortam dosyaları olarak saklayabilen bir sistem geliştirilmiştir. Bu sistem kullanılmaya başlandıktan sonra zaman içinde özellikle portfolyo bileşenlerine eklenecek yeni kriterler ve içerik ile çok daha objektif değerlendirmelere imkan sağlayacaktır.

Geliştirilen portfolyo dosya modülü, sistemin test çalışmaları sırasında .doc, .pdf, .ppt gibi yazılı ve sabit görselli dosyalar ile denenmiştir. Fakat daha büyük kapasiteli sunucular kullanıldığında hem teorik dersler hem de portfolyo çalışmalarına yönelik sisteme sesli video dosyaları da yüklenmesi ve öğrenciler için referans bir arşiv oluşturulması mümkün olabilecektir. Yeni geliştirilen her sistem ve yöntem gibi gerçeklenen bu sistem de zaman içinde kullanıldıkça ve kullanıcılardan alınan geri bildirimlerle olgunlaşacak ve daha işlevsel özellikler kazanacaktır.

\section{Teșekkür:}

113S827 Numaralı Web Tabanlı Tıp Eğitimi Yönetim Sistemi Geliştirilmesi projesine ve bilime katkılarından dolayı TUBITTAK'a teşekkür ederiz.

\section{KAYNAKLAR}

1. T.C. Yükseköğretim Kurulu, T.C. Sağlık Bakanlığı, T.C. Başbakanlık Devlet Planlama Teşkilatı Müsteşarlığı. Türkiye'de Sağlık Eğitimi ve Sağlık İnsangücü Durum Raporu. http://www.yok.gov.tr/documents/10279/30217 /turkiyede_saglik_egitimi/3eef8efe-9fbe-4e66bc05-15262a6ec747Accessed: 18.03.2016.

2. Türk Tabipleri Birliği. Türk Tabipleri Birliği Mezuniyet Öncesi Tıp Eğitimi Raporu-2010. https://www.ttb.org.tr/kutuphane/mote_2010.p dfAccessed: 21.04.2016.

3. Baysal Z, Cengiz M, Mordeniz C. Tıp fakültesi birinci sınıfında uygulanan temel yaşam desteği eğitiminin değerlendirilmesi. Sürekli Tıp Eğitimi Dergisi 2007;16(2):17-20.

4. Jason MS, Ellen H. Emotion skills training for medical students: a systematic review. Med Educ 2007;41:935-941.

5. Yılmaz ED. Tıp eğitimi sistemleri yöntemleri ve tıp fakültelerinin sorumlulukları. Trakya Üni Tip Fak Derg 2006;23:1-3.

6. Cox M, Irby DM. Assessment in Medical Education. N Engl J Med 2007;356:387-396.

7. Ak B. Türkiye'de sağlık bilişimi, bir kişisel değerlendirme ve uluslararası başarı öyküsü: CorTTex. Akademik Bilişim Konferansı 2009. http://ab.org.tr/ab09/kitap/ak_AB09.pdfAccess ed:14.12.2015.

8. Driessen E, Tartwijk JV, Vleuten CVD, Wass V. Portfolios in medical education: why do they meet with mixed success? A systematic review. Med Educ 2007;41:1224-1233.

9. Lurie S.J, Mooney CJ, Lyness JM. Measurement of the general competencies of the accreditation council for graduate medical education: a systematic review. Acad Med 2009;84:301-309.

10. Birgin O, Baki A. The use of portfolio to assess student's performance. Journal of Turkish Science Education 2007;4(2): 75-90.

11. The PHP Group. What is PHP. http://php.net/Accessed:12.02.2016.

12. Oracle. MySQL Documentation. https://dev.mysql.com/doc/Accessed: 28.06.2016.

13. Yükseköğretim Kurulu Başkanlığı. Mezuniyet Öncesi Tıp Eğitimi Ulusal Çekirdek Eğitim Programi-2014.

http://www.yok.gov.tr/documents/10279/27821 052/tip_fakultesi_cekirdek_egitim_mufredati.p dfAccessed: 09.07.2016. 